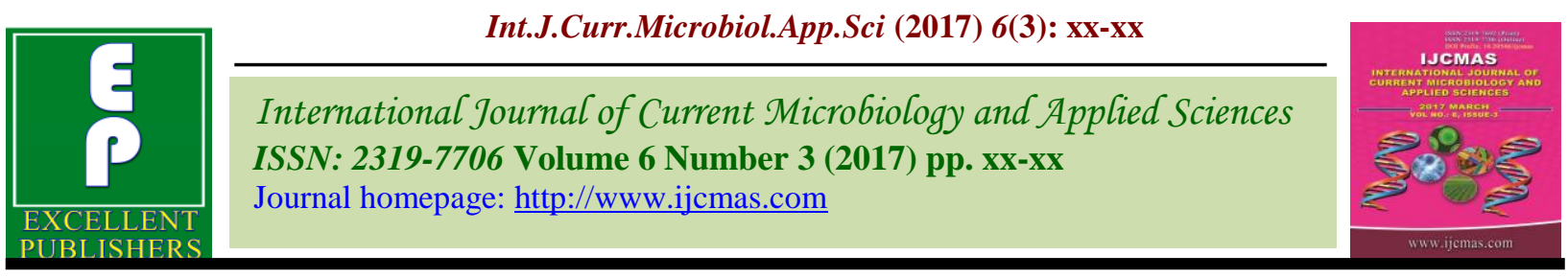

Original Research Article

https://doi.org/10.20546/ijcmas.2017.603.221

\title{
Effect of Nitrogen and Phosphorus on Yield and Yield Attributes of Maize in South Saurashtra, India
}

\author{
B. Pal $^{2}$, D.S. Hirpara ${ }^{1}$, V.D. Vora ${ }^{1}$, P.D. Vekaria ${ }^{1}$, G.S. Sutaria ${ }^{1}$, \\ K.N. Akbari ${ }^{1}$ and H.P. Verma ${ }^{1}$ \\ ${ }^{1}$ Main Dry Farming Research Station, Junagadh Agricultural University, \\ Targhadia -360 003, Gujarat, India \\ ${ }^{2}$ Department of Agronomy, College of Agriculture, Junagadh Agricultural University, \\ Junagadh- 362001, Gujarat, India \\ *Corresponding author
}

A B S T R A C T

Keywords

Nitrogen, Phosphorus, Yield, Yield attributes, Maize, Economics, Growth.

Article Info

Accepted:

24 February 2017 Available Online: 10 March 2017
A field experiment was conducted during kharif season of 2012 on calcareous soil to study the effect of 4 levels of nitrogen and 3 levels of phosphorus on yield and yield attributes of maize in South Saurastra. N (60, 80, 100 and $\left.120 \mathrm{~kg} \mathrm{ha}^{-1}\right)$ and $\mathrm{P}\left(40,50\right.$ and $60 \mathrm{~kg} \mathrm{P}_{2} \mathrm{O}_{5}$ ha $^{-}$ ${ }^{1}$ ) with twelve treatment combinations tested in factorial randomized block design with three replications. Results indicated that application of $120 \mathrm{~kg} \mathrm{~N} \mathrm{ha}^{-1}$ recorded the maximum plant height $(165.28 \mathrm{~cm})$, number of cobs per plant $(1.49)$, cob length $(17.87$ $\mathrm{cm})$, cob girth $(15.05 \mathrm{~cm})$, dry matter accumulation $\left(153.09 \mathrm{~g} \mathrm{plant}^{-1}\right)$, number of grains per cob (283.19), 100 grain weight $(26.70 \mathrm{~g})$, grain yield $\left(4905 \mathrm{~kg} \mathrm{ha}^{-1}\right)$, stover yield (8478 $\mathrm{kg} \mathrm{ha}^{-1}$ ), biological yield (13382 kg ha ${ }^{-1}$ ), net return (39228 ha-1) and BCR (3.14). Application of $60 \mathrm{~kg} \mathrm{P}_{2} \mathrm{O}_{5} \mathrm{ha}^{-1}$ recorded the maximum plant height $(159.16 \mathrm{~cm})$, number of cobs per plant (1.47), cob length $(17.58 \mathrm{~cm})$, cob girth $(14.99 \mathrm{~cm})$, dry matter accumulation (146.52 $\left.\mathrm{g} \mathrm{plant}^{-1}\right)$, number of grains per cob (275.74), 100 grain weight $(25.27 \mathrm{~g})$, grain yield $\left(4987 \mathrm{~kg} \mathrm{ha}^{-1}\right)$, stover yield (8281 kg ha $\left.{ }^{-1}\right)$, biological yield (13268 $\mathrm{kg} \mathrm{ha}^{-1}$ ), net return (38967 Rs. ha ${ }^{-1}$ ) and BCR (3.03).

\section{Introduction}

Maize (Zea mays L.) ranks third in total world production after wheat and rice and it is principal staple food in many countries, particularly in the tropics and subtropics. Maize is considered as the "Queen of Cereals". Being a $\mathrm{C}_{4}$ plant, it is capable to utilize solar radiation more efficiently even at higher radiation intensity. Maize assumes a special significance in Indian agriculture on account of its utilization as food, feed and fodder besides several industrial uses. Among different nutrients, nitrogen is the most commonly deficient nutrient in the soil and gives considerable response in maize crop. It has the quickest and the most pronounced effect on plant growth and development and ultimately on crop yield. Nitrogen is essential constituent of protein and is present in many other compounds of physiological importance in plant metabolism such as nucleotide, phosphatides, alkaloids, enzymes, hormones and vitamins etc. It has best physiological efficiency thus $\mathrm{N}$ will help in boosting higher yield. Phosphorus nutrition plays a key role in 
plant metabolism. It is most essential for all living creatures for their growth and development. Being involved in various biochemical processes, it ensures transfer and storage of energy as ADP and ATP, permits conversion and transmission of genetic characters, as it is a constituent of RNA and DNA. Therefore, the present study was carried out to find out the effect of $\mathrm{N}$ and $\mathrm{P}$ dosage on kharif maize.

\section{Materials and Methods}

A field experiment was conducted during kharif season of 2012 at Instructional Farm, Department of Agronomy, College of Agriculture, Junagadh Agricultural University, Junagadh situated at South Saurashtra agroclimatic zone - VII at latitude of 21.51' $\mathrm{N}$,longitude of 70.49' $\mathrm{E}$ and altitude $61.0 \mathrm{~m}$ above mean sea level. The soil was medium black, alkaline in reaction $(\mathrm{pH} \mathrm{8.0)}$, medium in organic carbon $(0.54 \%)$, low in available nitrogen $\left(238.0 \mathrm{~kg} \mathrm{ha}^{-1}\right)$, medium in available phosphorus $\left(27.50 \mathrm{~kg} \mathrm{P}_{2} \mathrm{O}_{5} \mathrm{ha}^{-1}\right)$ and potassium $\left(236.0 \mathrm{~kg} \mathrm{~K}_{2} \mathrm{O} \mathrm{ha}^{-1}\right)$ content. The experiment comprising twelve treatment combinations consisting four levels of nitrogen viz., 60, 80, 100 and $120 \mathrm{~kg} \mathrm{~N}^{-1}$ and three levels of phosphorus viz., 40, 50 and $60 \mathrm{~kg} \mathrm{P}_{2} \mathrm{O}_{5} \mathrm{ha}^{-1}$ were tested in a factorial randomized block design with three replications. Fertilizers were applied as per treatment through single super phosphate (SSP) and urea at the time of sowing as basal dose. The rainfall during kharif 2012 was $425.0 \mathrm{~mm}$ in 25 rainy days. The maize cv. 'GM-6' was sown on 18 July, 2012 using seed rate of $20 \mathrm{~kg} \mathrm{ha}^{-1}$ with a row spacing of $45 \mathrm{~cm}$ and harvested on 7 October, 2012. Four irrigations were applied during growing season. Intercultural operations viz., thinning, hoeing and weeding were followed after 20 days of sowing to maintain recommended spacing and weed control. For weed management atrazine @ $0.5 \mathrm{~kg} \mathrm{ha}^{-1}$ was applied as pre-emergence to control the weeds in early stages of the crop. Fully mature and develop cobs from randomly selected five plants from each plot were plucked and number of seeds were counted. The average number of cobs and seeds per plants was worked out. After threshing and winnowing the weight of seeds and also stover for each net plot area was recorded in $\mathrm{kg}$ per plot and then converted to $\mathrm{kg} \mathrm{ha}^{-1}$.

\section{Results and Discussion}

\section{Effect of nitrogen}

Growth parameters, yield attributes and yield of maize viz., plant height, number of cobs per plant, cob length, cob girth, dry matter accumulation, number of grains per cob, 100 grain weight, grain yield, stover yield, biological yield, net return and BCR were significantly influenced by nitrogen application and its levels (Table 4.1 and 4.2). Significantly, the highest values of these growth parameters, yield attribute and yield parameters were observed with application of $120 \mathrm{~kg} \mathrm{~N} \mathrm{ha}^{-1}$ and the lowest values were recorded under $60 \mathrm{~kg} \mathrm{~N} \mathrm{ha}^{-1}$. The increase in these components seems to have been brought about by increase in amount of growth and yield attributes substances and naturally occurring phytohormones with an increased nitrogen supply to the plant. Probably the increase in auxin supply with higher levels of nitrogen brought about increase in the dry matter and enhances the plant growth. This improvement might be due to an early and plentiful availability of nitrogen leading to better nutritional environment in the root zone for growth and development. As nitrogen is one of the major essential plant nutrients required for growth. Therefore, increased availability of nitrogen might have increased cell number and cell size leading to better growth in terms of plant growth. Nitrogen is an element of chlorophyll; it harnesses solar 
energy and fixes atmospheric $\mathrm{CO}_{2}$ as carbohydrates and amino acids. Thus, nitrogen application increased dry matter production. The increased supply of nitrogen and their higher uptake by plants might have stimulated the rate of various physiological processes in plant and leads to increased growth parameters, yield attribute and yield. The enhanced growth with nitrogen was also reported by Sofi et al., (2004), Yadav and Pandey (2005), Chillar and Kumar (2006), Kar et al., (2006), Patel et al., (2006), Bindhani et al., (2007), Sahoo and Mahapatra (2007).

Table.1 Effect of nitrogen and phosphorus levels on growth parameters of maize

\begin{tabular}{|c|c|c|c|c|c|}
\hline Treatment & $\begin{array}{l}\text { Plant height } \\
\text { (cm) }\end{array}$ & $\begin{array}{c}\text { Number of cobs } \\
\text { per plant }\end{array}$ & $\begin{array}{l}\text { Cob length } \\
\text { (cm) }\end{array}$ & $\begin{array}{l}\text { Cob girth } \\
(\mathrm{cm})\end{array}$ & $\begin{array}{c}\text { Dry matter } \\
\left(\mathrm{g} \mathrm{plant}^{-1}\right)\end{array}$ \\
\hline \multicolumn{6}{|c|}{ Nitrogen $\left(\mathrm{kg} \mathrm{N} \mathrm{ha}^{-1}\right)$} \\
\hline$N_{1}-60$ & 128.04 & 1.19 & 14.56 & 12.41 & 129.83 \\
\hline $\mathbf{N}_{2}-80$ & 141.30 & 1.32 & 15.85 & 13.40 & 140.83 \\
\hline$N_{3}-100$ & 157.65 & 1.40 & 17.22 & 14.43 & 149.92 \\
\hline$N_{4}-120$ & 165.28 & 1.49 & 17.87 & 15.05 & 153.09 \\
\hline S.Em. \pm & 3.45 & 0.04 & 0.39 & 0.32 & 3.58 \\
\hline $\mathrm{CD}(\mathrm{P}=0.05)$ & 10.13 & 0.10 & 1.16 & 0.95 & 10.51 \\
\hline \multicolumn{6}{|c|}{ Phosphorus $\left(\mathrm{kg} \mathrm{P}_{2} \mathrm{O}_{5} \mathrm{ha}^{-1}\right)$} \\
\hline$P_{1}-40$ & 137.38 & 1.21 & 15.08 & 12.55 & 137.62 \\
\hline $\mathbf{P}_{2}-\mathbf{5 0}$ & 147.67 & 1.37 & 16.47 & 13.93 & 146.11 \\
\hline$P_{3}-60$ & 159.16 & 1.47 & 17.58 & 14.99 & 146.52 \\
\hline S.Em. \pm & 2.99 & 0.03 & 0.34 & 0.28 & 3.10 \\
\hline $\mathrm{CD}(\mathrm{P}=0.05)$ & 8.78 & 0.09 & 1.00 & 0.82 & NS \\
\hline
\end{tabular}

Table.2 Effect of nitrogen and phosphorus levels on growth parameters, yield attribute, yield and economics of maize

\begin{tabular}{|c|c|c|c|c|c|c|c|}
\hline Treatment & $\begin{array}{c}\text { Number of } \\
\text { grains per } \\
\text { cob }\end{array}$ & $\begin{array}{l}100 \text { grain } \\
\text { weight }(\mathrm{g})\end{array}$ & $\begin{array}{c}\text { Grain } \\
\text { yield } \\
\left(\mathrm{kg} \mathrm{ha}^{-1}\right)\end{array}$ & $\begin{array}{c}\text { Stover } \\
\text { yield } \\
\left(\mathrm{kg} \mathrm{ha}^{-1}\right)\end{array}$ & $\begin{array}{c}\text { Biological } \\
\text { yield }\left(\mathrm{kg} \mathrm{ha}^{-1}\right)\end{array}$ & $\begin{array}{c}\text { Net } \\
\text { realization } \\
\left(\boldsymbol{F}^{-} \text {ha }^{-1}\right)\end{array}$ & $\mathbf{B C R}$ \\
\hline \multicolumn{8}{|c|}{ Nitrogen $\left(k \mathbf{N ~ h a}{ }^{-1}\right)$} \\
\hline$N_{1}-60$ & 226.70 & 19.81 & 4243 & 6096 & 10338 & 31006 & 2.76 \\
\hline $\mathbf{N}_{2}-\mathbf{8 0}$ & 250.97 & 21.86 & 4691 & 7016 & 11707 & 36148 & 3.03 \\
\hline $\mathrm{N}_{3}-100$ & 274.62 & 25.92 & 4820 & 8034 & 12855 & 38192 & 3.11 \\
\hline$N_{4}-120$ & 283.19 & 26.70 & 4905 & 8478 & 13382 & 39228 & 3.14 \\
\hline S.Em. \pm & 4.61 & 0.62 & 132 & 251 & 268 & - & - \\
\hline $\mathrm{CD}(\mathrm{P}=0.05)$ & 13.53 & 1.81 & 387 & 736 & 785 & - & - \\
\hline \multicolumn{8}{|c|}{ Phosphorus $\left(\mathrm{kg} \mathrm{P}_{2} \mathrm{O}_{5}\right.$ ha $\left.^{-1}\right)$} \\
\hline$P_{1}-40$ & 241.41 & 21.89 & 4343 & 6447 & 10790 & 31512 & 2.71 \\
\hline$P_{2}-50$ & 259.46 & 23.56 & 4664 & 7489 & 12153 & 35361 & 2.88 \\
\hline$P_{3}-60$ & 275.74 & 25.27 & 4987 & 8281 & 13268 & 38967 & 3.03 \\
\hline S.Em. \pm & 4.00 & 0.54 & 114 & 217 & 232 & - & - \\
\hline $\mathrm{CD}(\mathrm{P}=0.05)$ & 11.72 & 1.57 & 335 & 638 & 680 & - & - \\
\hline
\end{tabular}




\section{Effect of phosphorus}

Growth parameters, yield attribute and yield of maize viz., plant height, number of cobs per plant, cob length, cob girth, number of grains per cob, 100 grain weight, grain yield, stover yield, biological yield, net return and BCR were significantly influenced by phosphorus application and its levels (Table 4.1 and 4.2). Significantly the highest values of these growth parameters, yield attribute and yield parameters were observed with application of $60 \mathrm{~kg} \mathrm{P}_{2} \mathrm{O}_{5} \mathrm{ha}^{-1}$ which the lowest values were recorded under $40 \mathrm{~kg} \mathrm{P}_{2} \mathrm{O}_{5}$ $\mathrm{ha}^{-1}$. The improvement in growth parameters with application of $60 \mathrm{~kg} \mathrm{P}_{2} \mathrm{O}_{5} \mathrm{ha}^{-1}$ might have resulted in better and timely availability of $\mathrm{P}$ for their utilization by plant (Table 4.1 and 4.2). Phosphorus fertilization improves the various metabolic and physiological processes and thus known as "energy currency" which is subsequently used for vegetative and reproductive growth through photophosphorylation. In addition to vital metabolic role, $\mathrm{P}$ is an important structural component of nucleic acid, phytein, phospholipids and enzymes. An adequate supply of phosphorus early in the life cycle of plant is important in laying down the primordia of its reproductive part. It also increases the initiation of both first and second order rootlets and their development. The extensive root system helps in exploiting the maximum nutrients and water from the soil. Under the present investigation, profound influence of $\mathrm{P}$, a component of fertility management, on crop growth seem to be due to maintaining congenial nutritional environment of plant system on account of their greater availability from soil media. The significant improvement in nutrient status of plant parts (stover) might have resulted in greater synthesis of amino acids, proteins and growth promoting substances, which seems to have enhanced the meristematic activity and increased cell division and their elongation.
The enhanced growth with phosphorus was also reported by Patel et al., (2000), Arya and Singh (2001), Mehta (2002), Sahoo and Panda (2001) and Mehta et al., (2005).

On the basis of one year field experimentation, it seems quite logical to conclude that maximum production and net returns from kharif maize by the application of nitrogen and phosphorus @ 120 and $60 \mathrm{~kg}$ $\mathrm{ha}^{-1}$ on calcareous soil under South Saurashtra agro-climatic Zone.

\section{References}

Arya, K.C. and Singh, S.N. 2001. Effect of different levels of phosphorus and zinc on yield and nutrients uptake of maize (Zea mays L.) with and without irrigation. Indian J. Agri. Sci., 71: 5759.

Bindhani, A., Barik, K.C., Garnayak, L.M. and Mahapatra, P.K. 2007. Nitrogen management in baby corn (Zea mays). Indian J. Agron., 52: 135- 138.

Chillar, R.K. and Kumar, A. 2006. Growth and yield behaviour of sweet corn (Zea mays L. saccharata) under varying plant population and nitrogen level. In: Extended Summaries of Golden Jubilee National Symposium on Conservation Agriculture and Environment held during 26-28 October, 2006 at Banaras Hindu University, Varanasi, pp. 277278.

Kar, P.P., Barik, K.C., Mahapatra, P.K., Garnayak, L.M., Rath, B.S., Bastia, D.K. and Khanda, C.M. 2006. Effect of planting geometry and nitrogen on yield, economics and nitrogen uptake of sweet corn (Zea mays). Indian $J$. Agron., 51: 43-45.

Mehta, Y.K. 2002. Effect of sulphur, phosphorus and FYM on productivity of maize (Zea mays L.) and their residual effect on mustard [Brassica juncea (L.) 
at varying fertility levels. Ph.D. thesis submitted to Maharana Pratap University of Agriculture and Technology, Udaipur.

Mehta, Y.K., Shaktawat, M.S. and Singh, S.M. 2005. Influence of sulphur, phosphorus and farmyard manure on yield attributes and yield of maize (Zea mays L.) in southern Rajasthan conditions. Indian J. Agron., 50: 203-205.

Patel, G.J., Patel, G.N., Goyal, S.N. and Patel, B.G. 2000. Effect of phosphorus on the growth and yield of hybrid maize (Zea mays L.).Gujarat Agri. University Res. J., 26(1): 59-60.

Patel, S.K., Tank, D.A. and Usadadia, V.P. 2006. Nitrogen management in rabi maize (Zea mays L.). Crop Res. Hisar, 31(2): 323-324.

Sahoo, S.C. and Mahapatra, P.K. 2007. Yield and economics of sweet corn (Zea mays) as affected by plant population and fertility levels. Indian J. Agron., 52(3): 239-242.

Sahoo, S.C. and Panda, M.M. 2001. Effect of phosphorus on yield of baby corn (Zea mays L.). Indian J. Agri. Sci., 71(1): 2122.

Sofi, K.A., Sharma, D.P. and Thomas, T. 2004. Effect of nitrogen and potassium nutrition on yield, nutrient uptake and soil fertility of maize (Zea mays) under rainfed condition of Uttar Pradesh. Environ. Ecol., 22(spl-3): 483-485.

Yadav, R.S. and Pandey, S.M. 2005. Relative performance of QPM full season at Bahraich. 48th Annual Progress Report, AICMIP, Directorate of Maize Research, New Delhi, A-44.

\section{How to cite this article:}

Pal, B., D.S. Hirpara, V.D. Vora, P.D. Vekaria, G.S. Sutaria, K.N. Akbari and H.P. Verma. 2017. Effect of Nitrogen and Phosphorus on Yield and Yield Attributes of Maize in South Saurashtra. Int.J.Curr.Microbiol.App.Sci. 6(3): 1945-1949.

doi: https://doi.org/10.20546/ijcmas.2017.603.221 